\title{
Selectivity of Entomopathogenic Fungi to Chrysoperla externa (Neuroptera: Chrysopidae)
}

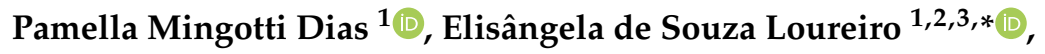 \\ Luis Gustavo Amorim Pessoa 2,3 (1) Gabriel Luiz Reis Devoz ${ }^{2}$, Gilson Bárbaro Barbosa Junior ${ }^{3}$, \\ Allan Macali Werner ${ }^{3}{ }^{-}$, Acacio Aparecido Navarrete ${ }^{3}$ and Paulo Eduardo Teodoro ${ }^{2,3}$ \\ 1 Graduate Program in Entomology and Biodiversity Conservation, Federal University of Grande Dourados, \\ Dourados 79804-970, Brazil; pamellamingotti@hotmail.com \\ 2 Agronomy, Federal University of Mato Grosso do Sul, Chapadão do Sul 79560-000, Brazil; \\ luis.pessoa@ufms.br (L.G.A.P.); gabriel.devoz@gmail.com (G.L.R.D.); paulo.teodoro@ufms.br (P.E.T.) \\ 3 Graduate Program in Agronomy, Area of Concentration in Crop Science, Federal University of Mato Grosso \\ do Sul, Chapadão do Sul 79560-000, Brazil; gilson.barbarobarbosa@gmail.com (G.B.B.J.); \\ allanwerner@hotmail.com (A.M.W.); acacionavarrete@gmail.com (A.A.N.) \\ * Correspondence: elisangela.loureiro@ufms.br
}

Received: 13 September 2020; Accepted: 13 October 2020; Published: 19 October 2020

check for updates

Simple Summary: Agricultural crop systems have adopted integrated management as a model of success in pest control; however, chemical control is still prioritized. The use of pesticides incorrectly and excessively has provided a reduction in natural enemies, selection of resistant populations and resurgence of pests. Chrysoperla externa is a predator found in several regions in Brazil that preys on different pest insects. Entomopathogenic fungi Beauveria and Metarhizium also stand out for causing epizootics on pests. Both predators and entomopathogens can simultaneously act as pest control; thus, verifying the selectivity of entomopathogenic fungi to predators increases the potential for biological control through synergism and conservation of natural enemies in the agroecosystem. Considering the control potential of these different biological control agents, in this study we evaluated the selectivity of Beauveria bassiana, Metarhizium anisopliae and Metarhizium rileyi to the larvae of this predator. The results provide evidence that the biological development of larvae of $C$. externa is not influenced by the entomopathogenic fungus. These species of fungi can be recommended, aiming at a management of populations of arthropod pests, with low effect on C. externa when it is present in the agrosystem.

\begin{abstract}
We aimed to evaluate the selectivity of entomopathogenic fungi to larvae of Chrysoperla externa (Neuroptera: Chrysopidae). For this purpose, Beauveria bassiana (strain ESALQ PL63), Metarhizium anisopliae (strain ESALQ E9) and Metarhizium rileyi (strain UFMS 03) were assessed at different concentrations $\left(1 \times 10^{7}, 1 \times 10^{8}\right.$ and $1 \times 10^{9}$ conidia $\left.\mathrm{mL}^{-1}\right)$. The control treatment consisted of distilled water and Tween 80 0.01. The treatments were applied with a Potter spray tower using two different methodologies: direct application (DA) and dry film (DF). Up to $96 \mathrm{~h}$ after application, no treatment provided a larval mortality above $3 \%$. After $120 \mathrm{~h}$, only B. bassiana induced significant mortality in all instars, with rates of $26 \%, 17 \%$ and $10 \%$ for first, second and third instar larval periods, respectively. There was no difference regarding to the application method or concentration of conidia. The percentage of individuals that revealed changes in the length of the larval and pupal periods varied among different treatments with entomopathogenic fungi and control treatments, application methodologies and concentrations. Despite B. bassiana revealing a higher mortality than M. anisopliae and $M$. rileyi on larvae of $C$. externa, these three entomopathogenic fungi may be used in association with C. externa for sustainable pest management.
\end{abstract}


Keywords: Hypocreales; entomopathogens; microbial control; entomophagous; predator; green lacewing; integrated pest management; sustainability

\section{Introduction}

Neotropical fauna of green lacewings present high diversity, with 82 genera [1]. The Chrysoperla externa species (Hagen, 1861) (Neuroptera: Chrysopidae) is commonly found in Brazil, with reports of occurrence in different regions [2]. Studies have shown the effectiveness of this predatory species in the biological control of pest arthropods (such as aphids and whiteflies), eggs and small caterpillars, as well as in field and controlled conditions for cotton, wheat, sorghum, citrus, peach and melon crops [3-14]. In addition to prey generalism, C. externa has aroused interest in biological control research due to the ease of its mass production in the laboratory and its environmental adaptability [10,11].

Entomopathogenic fungi are important regulators of pest arthropods due to the natural action of these microorganisms through natural epizootic diseases [15]. In the system of integrated pest management (IPM), the fungi belonging to the genera Beauveria, Metarhizium and Isaria are widely used in the biological control of several arthropod pests [16,17]. The adoption of IPM in agricultural production systems has been considered a success [18,19]; however, chemical control is still a priority due to the desire to lower production costs and improve the lack of suitable information about the association of management tools applicable in the fields $[19,20]$.

The incorrect and excessive use of pesticides has led to reductions of natural enemies, selections of resistant populations and resurgences of pests [20-22]. Selective phytosanitary products may intervene in the development and survival of entomophagous insects and entomopathogenic microorganisms [23-25]. There are reports of the negative effects of pesticides at all stages of development of C. externa [26-30]. The selectivity of the entomopathogenic fungi concerning green lacewings raises the potential for biological control by the synergism and conservation of natural enemies in the agroecosystem. The entomopathogenic fungi used to control pests in Brazil has been shown to be selective in the species of green lacewings C. externa and Ceraeochrysa cincta (Neuroptera: Chrysopidae) [29-33].

Due to the information presented on the Chrysopidae, we would like to obtain better insight into the actions of the entomopathogenic fungi Beauveria bassiana (strain ESALQ PL63), Metarhizium anisopliae (strain ESALQ E9) and Metarhizium rileyi (strain UFMS 03) based on the mortality and duration of the first-, second- and third-instar (larval) periods of C. externa at 24, 48, 72, 96 and $120 \mathrm{~h}$ after fungi application.

\section{Materials and Methods}

\subsection{Obtaining Fungi}

The fungi B. bassiana (strain ESALQ PL63) and M. anisopliae (strain ESALQ E9) were obtained from the microbiological insecticides BOVERIL and METARRIL, respectively. However, because no commercial formulas contain $M$. rileyi (strain UFMS 03), this isolate was produced following the methods described by Dias et al. [34]. Sabouraud media, temperature and relative humidity $\left(25 \pm 1^{\circ} \mathrm{C}\right.$, $70 \pm 10 \%$ of relative humidity), with a photoperiod of $12 \mathrm{~h}$ (light/dark = L:D), were also used to obtain the isolate of $M$. rileyi. To prepare fungal suspensions, the isolates were diluted using sterile distilled water that contained $0.01 \%(v / v)$ Tween 80 , and the conidia were counted using a Neubauer chamber to standardize the concentrations.

\subsection{Obtaining and Rearing Chrysoperla externa}

Adults of C. externa were collected in corn crops at the Federal University of Mato Grosso do Sul, Campus of Chapadão do Sul, MS, Brazil, where chemicals had not been sprayed. After this, adults 
were kept in 10-cm-diameter PVC (polyvinyl chloride) cages (height $23 \mathrm{~cm}$ ), which were lined with white bond paper for oviposition, with the lower end supported by styrofoam lined with paper and the upper end sealed with VOILE fabric. Insects were fed an artificial diet of brewer's yeast and honey, as described by Ribeiro [35]. The diet was provided using an adapted feeder made up of a soft sponge containing a paste diet over the top base and a bottom part inserted into a $10-\mathrm{mL}$ cylindrical tube with distilled water, according to the methodology described by Dias et al. [36].

Eggs were removed from the oviposition substrate using either scissors or a fine plastic comb at $24 \mathrm{~h}$ after oviposition. The eggs (10 each) were then transferred to 500-mL plastic containers that had been properly sanitized using $70 \%$ alcohol and $12 \mathrm{~h}$ of UV irradiation. The containers (i.e., cages) contained strips of paper to create a refuge for the larvae against cannibalism. Larvae were fed with sterilized eggs of Anagasta kuehniella (Zeller) (Lepidoptera: Pyralidae) daily until sufficient numbers of larvae were available for bioassays [10]. All insects were stored in an acclimatized room (temperature of $25 \pm 1{ }^{\circ} \mathrm{C}, 70 \pm 10 \%$ relative humidity (RH), and photoperiod of $\left.12 \mathrm{~h}(\mathrm{~L}: \mathrm{D})\right)$.

\subsection{Effects of the Entomopathogenic Fungi in the Chrysoperla externa Larvae}

Under controlled conditions with a temperature of $25 \pm 1{ }^{\circ} \mathrm{C}, 70 \pm 10 \% \mathrm{RH}$, and a photoperiod of $12 \mathrm{~h}$ (L:D), larvae of first, second and third instars of C. externa were separated and placed in Petri dishes (Supplementary Figure S1A-C). With a Potter spray tower adjusted to the pressure of $1.5 \mathrm{MPa}$, $2 \mathrm{~mL}$ of the following treatments were given: a control comprising sterilized distilled water and $0.01 \%$ $(v / v)$ Tween 80 (Sigma-Aldrich, Saint Louis, USA); and B. bassiana (strain ESALQ PL63), M. anisopliae (strain ESALQ E9) and $M$. rileyi (strain UFMS 03), each at a concentrations of $1 \times 10^{7}, 1 \times 10^{8}$ and $1 \times 10^{9}$ conidia $\mathrm{mL}^{-1}$. Into all fungal suspensions, $0.01 \%(v / v)$ of Tween 80 was added (Supplementary Figure S1D). Two methodologies were used: the first was the direct application (DA) of the treatments on the larvae of first, second and third instars inside Petri dishes (Anidrol, Diadema, Brazil) (called arenas) [37] (Supplementary Figure S1E); the second methodology involved dry film (DF), in which the treatments were applied on the arenas, with the insertion of larvae after drying the excess moisture (Supplementary Figure S1F), according to the model proposed by the International Organization for Biological and Integrated Control of Harmful Animals and Plants, Western Palearctic Regional Section (IOBC/WPRS) [38,39]. After the treatments were applied, all insects were fed sterilized eggs of A. kuehniella (Zeller) (Lepidoptera: Pyralidae) daily.

After the application and drying, the Petri dishes were sealed with plastic film and treated insects were placed within the biological oxygen demand (BOD) (Eletrolab, Campinas, Brazil) chamber under the following conditions: temperature $25 \pm 1{ }^{\circ} \mathrm{C}$, relative humidity $70 \pm 10 \%$ and a photoperiod of $12 \mathrm{~h}$ (L:D). Larvae were supplied with a standard diet (A. kuehniella eggs) according to the nutritional needs in each instar [40].

The larval mortality and percentage of insects at each growing stage were determined by $24,48,72$, 96 and 120 growing hours after application (HAA). For confirmation of larval mortality, the dead bodies were superficially disinfected with 70\% alcohol (Copersucar SA, São Paulo, Brazil) and sterile distilled water, three consecutive times, then placed in a humid chamber [31] under the following conditions: temperature $25 \pm 1{ }^{\circ} \mathrm{C}$, relative humidity $70 \pm 10 \%$ and a photoperiod of $12 \mathrm{~h}$ (L:D), (Supplementary Figure S2A-C).

For the third instar (larval) period that survived treatments, the evaluations were extended to 168 HAA, counting the percentage of individuals who had reached the pre-pupal and pupal stages. The duration (days) of these stages was also evaluated. The pupal viability was evaluated by the emergence of adults.

Adult viability was evaluated until $24 \mathrm{~h}$ after their emergence. Insects were considered viable when they had regular morphological specifications: whole antennae, compound eyes, full abdomen, total opening of the wings and a length between 20 and $23 \mathrm{~mm}$. This visual scale was adopted based on information available in the literature [11] (Supplementary Figure S3A-C). 


\subsection{Statistical Analysis}

The experimental design was completely randomized, with four replications in a factorial scheme. The first factor comprised four fungal strains ( $\mathrm{P}=$ products); the second factor was represented by four concentrations ( $\mathrm{C}=$ control treatment, $1 \times 10^{7}, 1 \times 10^{8}$ and $1 \times 10^{9}$ conidia $\left.\mathrm{mL}^{-1}\right)$; and the third factor involved two application methods $(\mathrm{A}=$ direct application $(\mathrm{DA})$ and dry film $(\mathrm{DF})$ ).

A Shapiro-Wilk test was used to verify the normality of the residuals for all evaluated variables. After verifying the normal distribution adjustment at $5 \%$ probability, we performed an analysis of variance (ANOVA). In the three-way ANOVA, the isolated effects of $\mathrm{P}, \mathrm{C}$ and $\mathrm{A}$ were tested, as well as their interactions $(\mathrm{P} \times \mathrm{A}, \mathrm{P} \times \mathrm{C}, \mathrm{A} \times \mathrm{C}$ and $\mathrm{P} \times \mathrm{A} \times \mathrm{C})$. When we detected significance, we applied a Tukey test at $5 \%$ probability for the comparison of means. All analyses were performed with the free software Rbio (Federal University of Viçosa, Viçosa, Brazil) [41].

\section{Results}

\subsection{Mortality of Chrysoperla externa Larvae}

In all instars, larvae of $C$. externa showed significantly higher susceptibility ( $p$-value $<0.05$ ) to the $(\mathrm{P})$ at 120 HAA. Survival of first instar (larval) period from 24 to 120 HAA was not influenced by the application methods $(\mathrm{A})$, concentrations $(\mathrm{C})$ or interactions $(\mathrm{P} \times \mathrm{A}, \mathrm{P} \times \mathrm{C}, \mathrm{A} \times \mathrm{C}$ and $\mathrm{P} \times \mathrm{A} \times \mathrm{C})$ ( $p$-value > 0.05; Supplementary Tables S1-S3).

From 24 to $96 \mathrm{HAA}$, the percentage of dead insects (3\%) observed for the first instar (larval) period of C. externa was not influenced by the isolate factors $(\mathrm{P}, \mathrm{A}$ and $\mathrm{C})$ or its interactions $(\mathrm{P} \times \mathrm{A}, \mathrm{P} \times \mathrm{C}$, $\mathrm{A} \times \mathrm{C}$ and $\mathrm{P} \times \mathrm{A} \times \mathrm{C})$. Only B. bassiana showed slightly higher mortality $(26 \%)$ than other strains at 120 HAA (Figure 1A).

For factor A, mortality was recorded as $15 \%$ and $13 \%$ at 120 HAA for the first instar (larval) period exposed to the methodologies DA and DF, respectively. Mortality observed at 120 HAA was $19 \%$, $15 \%$ and $10 \%$ for concentrations in the order of $1 \times 10^{7}, 1 \times 10^{8}$ and $1 \times 10^{9}$ conidia $\mathrm{mL}^{-1}$, respectively (Figure 1B,C).

The mortality by B. bassiana (P) was higher for the second instar (17\%) at $120 \mathrm{HHA}$; for factor A, mortalities of $8 \%$ for DA and $7 \%$ for DF were observed, while for factor $C$ mortalities of $10 \%, 7 \%$ and $8 \%$ were observed relative to concentrations $1 \times 10^{7}, 1 \times 10^{8}$ and $1 \times 10^{9}$ conidia $\mathrm{mL}^{-1}$, respectively (Figure 1D-F).

For the third instar, the highest mortality shown by B. bassiana at 120 HAA was $10 \%$. Factors A and $\mathrm{C}$ recorded mortalities of $6 \%$ in DA and $5 \%$ in DF; and factor $\mathrm{C}$ recorded mortalities of $5 \%, 8 \%$ and $4 \%$ in concentrations of $1 \times 10^{7}, 1 \times 10^{8}$ and $1 \times 10^{9}$ conidia $\mathrm{mL}^{-1}$, respectively (Figure 1G-I).

Confirmed mortality was observed in all dead bodies of larvae infected with B. bassiana (Supplementary Figure S4A-C). 

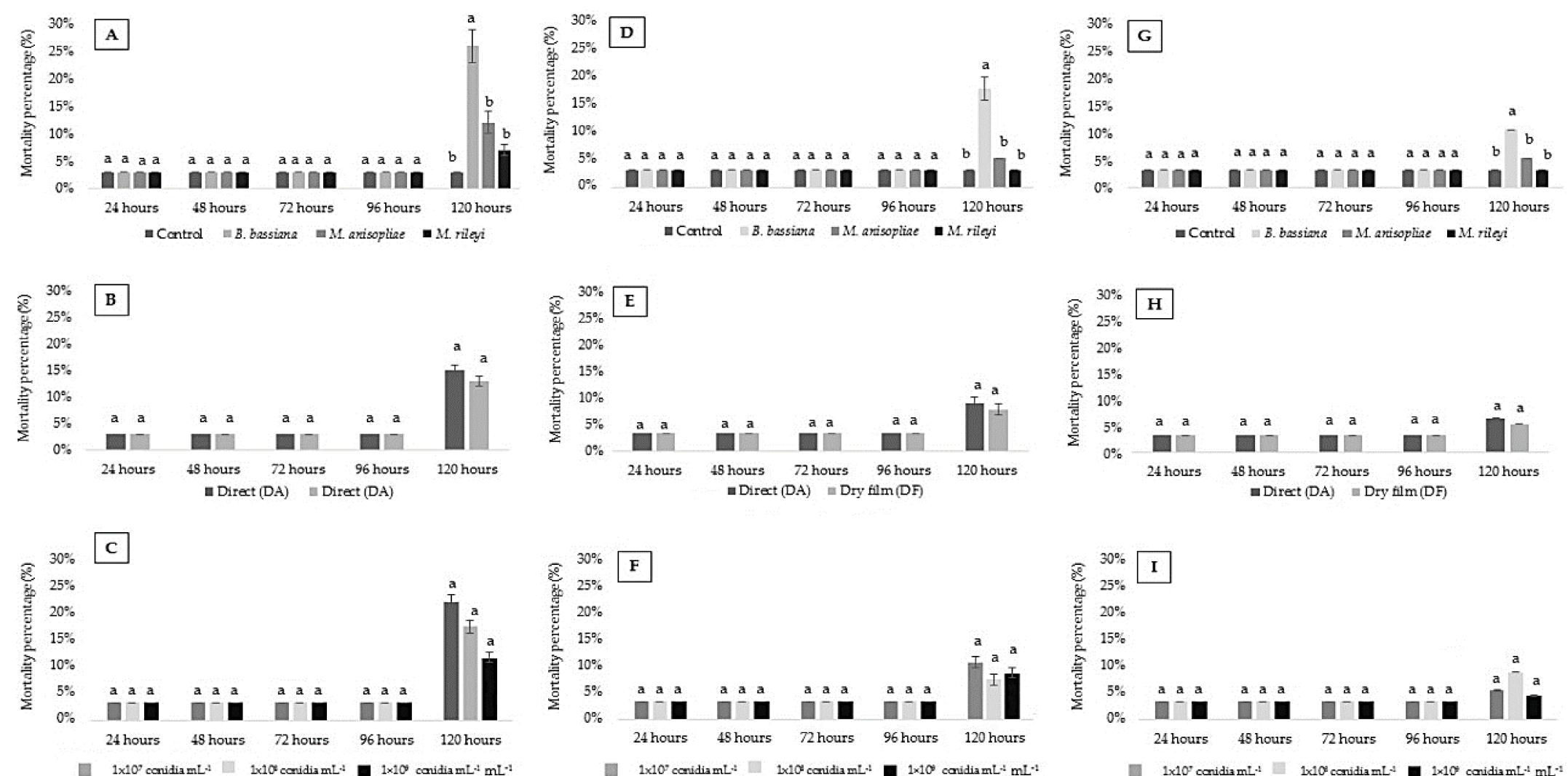

Figure 1. Mortality percentage ( $\% \pm$ standard error) of the first, second and third Chrysoperla externa larvae after each period of application of entomopathogenic fungi Beauveria bassiana, Metarhizium anisopliae and Metarhizium rileyi $\left(\mathrm{T}: 25 \pm 1{ }^{\circ} \mathrm{C}, \mathrm{RH} 70 \pm 10 \%\right.$ and $12 \mathrm{~h}$ photoperiod (light/dark)). (A-C) First instance mortality factor $=$ $\mathrm{P}$ (products), A (application methods) and C (concentrations), respectively. (D-F) Second instar mortality factor = P (products), A (application methods) and C (concentrations), respectively. (G-I) Third instar mortality factor $=$ P (products), A (application METHODS) and C (concentrations), respectively. Values (\%) followed by equal letters at each assessment time do not differ from each other according to a Tukey test at $5 \%$ probability. 


\subsection{Change of Larval State of C. externa Larvae}

For the first instar of C. externa, there was a significant effect of the treatments applied (P), with significant differences from 48 to $120 \mathrm{HAA}$. There were differences among the concentrations $(\mathrm{C})$ only in the evaluation of 120 HAA ( $p$-value < 0.05; Supplementary Table S4).

For the second instar, variations in change of the larval stage were observed at 72 and 96 HAA, with significant differences only for the products (P) ( $p<0.05$; Supplementary Table S5).

For the third instar of $C$. externa, there was a significant effect of the applied treatments $(P)$, application methods (A) and concentrations (C) at 72 HAA, but only for the applied treatments (P) and concentrations (C) at 120 HAA ( $p$-value < 0.05; Supplementary Table S6).

Most larvae changed their instar between 48 and 120 HAA, influenced only by the products (P) $(p<0.05$; Figure 2A). At 48 HAA, the control treatment provided the largest number of insects that changed stage, from the third instar to pupal stage (73\%) compared with the other treatments. At $72 \mathrm{HAA}$, a higher percentage (48\%) of larvae infected with the fungus $M$. rileyi showed a change of stage compared with the other treatments, followed by treatment with M. anisopliae (31\%); both showed significant differences compared with the control and B. bassiana (13\%). At 96 HAA, a smaller percentage $(16 \%)$ of the larvae of the control treatment showed a change of stage than B. bassiana (43\%) and M. rileyi $(32 \%)$. At $120 \mathrm{HAA}$, a larger percentage of larvae treated with B. bassiana (17\%) and M. anisopliae $(28 \%)$ experienced a change of stage than the control (3\%). However, M. anisopliae showed a higher percentage (28\%) of instar change compared to the control (3\%) and M. rileyi (7\%) (Figure $2 \mathrm{~A})$.

Regarding the concentrations $(\mathrm{C})$, only $1 \times 10^{8}$ conidia $\mathrm{mL}^{-1}$ provided a reduction in the percentage of insects that presented a change of stage ( $p$-value $<0.05$; Figure $2 \mathrm{C}$ ).

For the second instar, the change to the subsequent larval stage was more intense between 72 and 96 HAA. Treatment with B. bassiana provided a lower rate of change from the second to third instar than the control treatment. The $M$. rileyi treatment revealed a higher percentage of larvae that underwent a change in stage than the control treatment at 96 HAA (Figure 2D-F).

At each evaluation time, it was noticed that the larvae of the control treatment began the process of changing their larval state beginning at 72 HAA, with a higher average than the other fungal strains (P). In this period, variations were also observed for the factor application methods, and DA had a higher average than DF. The concentration of $1 \times 10^{9}$ conidia $\mathrm{mL}^{-1}$ had a lower average than the concentration of $1 \times 10^{7}$ conidia $\mathrm{mL}^{-1}$ (Figure $2 \mathrm{G}-\mathrm{I}$ ). 

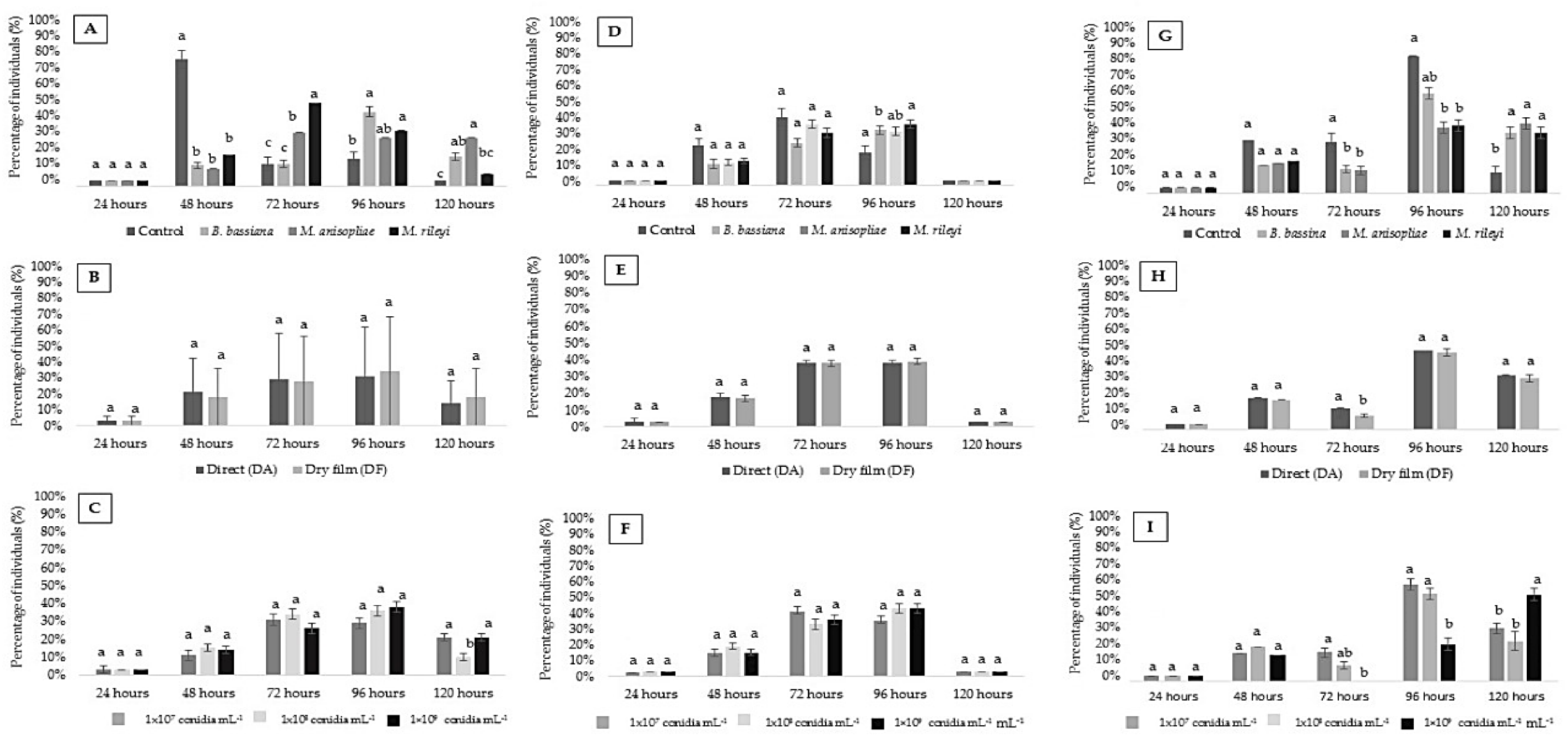

Figure 2. Percentage of Chrysoperla externa first, second and third instar (larval) period ( $\% \pm$ standard error) that changed their instar in each larval period after application of entomopathogenic fungi Beauveria bassiana, Metarhizium anisopliae and Metarhizium rileyi (T: $25 \pm 1{ }^{\circ} \mathrm{C}, \mathrm{RH} 70 \pm 10 \%$ and $12 \mathrm{~h}$ photoperiod (light/dark)). $(\mathrm{A}-\mathrm{C})$ Individuals who changed from first to second urge, factor $=\mathrm{P}$ (products), A (application methods) and C (concentrations), respectively. (D-F) Individuals who changed from second to third instar, factor $=\mathrm{P}$ (products), A (application methods) and C (concentrations), respectively. (G-I) Individuals who changed from third instar to the pre-pupa, factor $=\mathrm{P}$ (products), A (application methods) and C (concentrations), respectively. Values (\%) followed by equal letters at each assessment time do not differ from each according to a Tukey test at $5 \%$ probability. 


\subsection{Duration (Days) Pupal Period}

The third instar larvae of $C$. externa that survived the treatments began transitioning to pre-pupae as from 72 HAA. All larvae reached the pre-pupae stage at $120 \mathrm{HAA}$ with the influence of the products (P), application methods (A) and concentrations (C) ( $p$-value < 0.05; Supplementary Table S7).

All insects that survived and transformed in pupae made their cocoons between 148 and 164 HAA, with significant differences only for the products $(\mathrm{P})$ ( $p$-value < 0.05; Supplementary Table S6). There was no influence of products $(\mathrm{P})$, application methods $(\mathrm{A})$, concentrations $(\mathrm{C})$ or interactions $(\mathrm{P} \times \mathrm{A}, \mathrm{P} \times \mathrm{C}, \mathrm{A} \times \mathrm{C}$ and $\mathrm{P} \times \mathrm{A} \times \mathrm{C})$ on the pupal stage $(p$-value $<0.05$; Supplementary Table S7)

At 96 HAA, the larvae treated with $M$. anisopliae and $M$. rileyi had a lower average duration of pre-pupae stage than those with the control treatment; the concentration of $1 \times 10^{9}$ conidia mL $^{-1}$ had a lower mean variation in the larval period than the other treatments (Figure 3A). At 120 HAA, all insects had concluded the pre-pupae stage, the control treatment had a lower mean than the entomopathogenic fungi and the concentration of $1 \times 10^{9}$ conidia $\mathrm{mL}^{-1}$ had a higher mean than the other concentrations (Figure 3C).
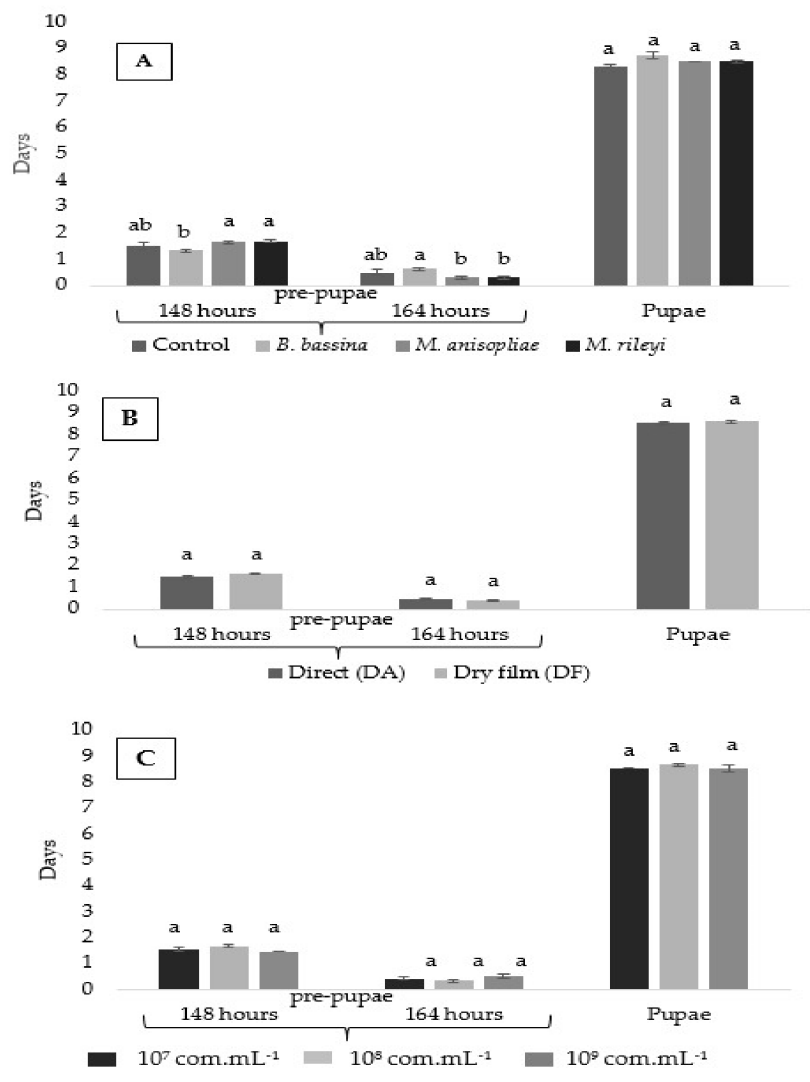

Figure 3. Average number (mean \pm standard error) of the duration of pre-pupae and pupae of Chrysoperla externa after application of the entomopathogenic fungi Beauveria bassiana, Metarhizium anisopliae and Metarhizium rileyi (T: $25 \pm 1{ }^{\circ} \mathrm{C}$, $\mathrm{RH}$ of $70 \pm 10 \%$ and photoperiod of $12 \mathrm{~h}$ (light/dark)). Duration in days for each stage according to factors: (A) product, (B) method of application and (C) concentrations. Means followed by equal letters at each assessment time do not differ from each according to a Tukey test at $5 \%$ probability.

From 148 to 164 HAA, all lacewings reached the pupal stage; in this period, a higher duration was recorded for larvae treated with $B$. bassiana than $M$. anisopliae and $M$. rileyi. The duration of the pupal period did not vary in relation to the treatments applied to the third-instar (larval) period of C. externa. (Figure 3A-C). 
The pupae had $100 \%$ viability, confirmed by the emergence of all adult individuals. The adults showed no visual morphological deformities, and all had whole antennas, compound eyes, full abdomen and sizes between 21 and $23 \mathrm{~mm}$ (Supplementary Figure S5A-C).

\section{Discussion}

The low mortality rate of C. externa larvae treated with M. anisopliae (ESALQ E9) and M. rileyi (UFMS 03) indicate selectivity of these isolates in green lacewing larvae. These results corroborate the selectivity of M. anisopliae (E9) reported on the first instar (larval) period of C. cincta [31].

The mortality rate in the larval stage of C. externa due to the fungus B. bassiana (ESALQ PL63) was observed at $120 \mathrm{HAA}$. This period can be considered suitable for the colonization of the lacewing larvae, since the germination of conidia on the host usually occurs $12 \mathrm{~h}$ after inoculation, with the penetration of hemocele in $24 \mathrm{~h}$, colonization occurring between three to five days and death occurring from six to seven days post-infection [42].

In Petri dishes that received treatment with B. bassiana, after drying, the formation of a white-colored adhesive film on the conidia was observed due to the excess moisture. This adhesive film maintained the artificial diet's adherence to the surface of the Petri dishes and reduced the larvae mobility. The susceptibility of the larval stage of C. externa to the fungus B. bassiana is possibly related to the adhesive that the treatment provided on the Neuroptera exoskeleton. In this case, the product BOVERIL possibly favored the adherence and penetration of the conidia on the cuticle of the C. externa larvae. The mode of infection of the entomopathogenic fungi is via integument and involves processes of adherence and penetration of the pathogen on the insect cuticle, overcoming physical and chemical barriers to later cause the germination [43-46]. Previous studies have shown that the interaction of adjuvants with entomopathogenic fungi Isaria fumosorosea (strain ESALQ-1296) and B. bassiana (strain ESALQ-PL63) enhances the pathogen action on the Asian citrus psyllid Diaphorina citri Kuwayama (Hemiptera, Liviidae) upon the physical and mechanical processes of infection by the integument $[47,48]$. The selectivity of the entomopathogenic fungi to entomophagous insects depends on several factors, among them, the formulation of emulsifiers, adjuvants and oils [46].

Although there was higher mortality for B. bassiana-infected larvae, at 120 HAA the percentages obtained in the present study were lower than $30 \%$. Studies with entomopathogens consider the pathogen when it reaches $40 \%$ host death [49-52]. By considering the pathogenic action of these fungi on green lacewing larvae, we can assume selectivity regarding the survival of individuals in the second and third instar.

The findings of the present study corroborate results obtained by other studies that showed selectivity or compatibility of B. bassiana isolates with low mortality rates ( $<30 \%)$ on green lacewing species such as the first instar (larval) period of Chrysopa exterior Navás (Neuroptera, Chrysopidae) [53], the third instar (larval) period of C. externa [30] and the larval stage of C. externa [54].

Although the present study evaluated three different concentrations $\left(1 \times 10^{7}, 1 \times 10^{8}\right.$ and $1 \times 10^{9}$ conidia $\mathrm{mL}^{-1}$ ) for each of the entomopathogenic fungi, the mortality of C. externa was not influenced by an increase of the concentrations. Studies with the third instar (larval) period of Chrysoperla kolthoffi Navás (1927) (Neuroptera: Chrysopidae) treated with M. anisopliae var. anisopliae showed an increase of mortality starting from the concentration of $1.5 \times 10^{8}$ conidia $\mathrm{mL}^{-1}$ and $100 \%$ mortality for concentrations higher than $1.5 \times 10^{12}$ conidia $\mathrm{mL}^{-1}$ [55]. In general, suspensions of entomopathogenic fungi did not affect the development of the biological cycle of C. externa; for those that presented the pupal phase and later, $100 \%$ of adults emerged. The studies with M. anisopliae var. anisopliae in early stage C. kolthoffi larvae showed that $75.8 \%$ of emerging adults were treated with the lowest concentrations $\left(1.5 \times 10^{4}\right.$ and $1.5 \times 10^{7}$ conidia $\left.\mathrm{mL}^{-1}\right)$ of the fungus [56].

Variations in the duration of larval, pre-pupae and pupae stages were not related to treatments with entomopathogenic fungi, concentrations or application methods, as there were also variations of these stages in the control insects. The variations in the duration of the larval stages are possibly related to the metabolism of each larva and the food consumption during each stage. The changes of instars of 
chrysopids are associated with the quantity and quality of prey consumed to meet the nutrient needs of each larval stage because all the reserves of the larval stage will be used in the prepupae and pupae stage and in the initial reproduction phase [11]. Generally, the lowest larval period was recorded for the second instar, a fact that can be attributed to the biological characteristics of the species [57,58].

The results obtained from this study evidence that the biological development of larvae of C. externa was not influenced by the fungus B. bassiana (strain ESALQ PL63), M. anisopliae (strain ESALQ E9) or $M$. rileyi (strain UFMS 03). These species of fungi can be recommended, aiming at the management of populations of arthropod pests, with a low effect on C. externa when it is present in the agrosystem.

These results indicate that there are possibilities for new research to validate the selectivity of these strains concerning the other development stages of C. externa. Thus, it is necessary to carry out studies to verify the effect of other strains or biobased products on the development of different species of green lacewings for various regions of Brazil.

New investigations are justified due to the high diversity of fungal strains from Brazil and the importance of determining factors for their mortality, such as the genetic variability of each isolate [59,60], the behavior and physiological condition of the host [61], the defense mechanisms used by insects [44,62-65], the lethal dose [66] and the compatibility and interaction with the entomophagous insects $[30,54,66,67]$.

\section{Conclusions}

There was no effect of fungi concentrations or application methods on all larval stages of $C$. externa. Although the B. bassiana strain induced higher mortality than $M$. anisopliae and M. rileyi strains on larvae of $C$. externa, these three entomopathogenic fungi may be used in association with C. externa for sustainable pest management.

Supplementary Materials: The following are available online at http://www.mdpi.com/2075-4450/11/10/716/s1, Figure S1: Mortality of entomopathogens biossay on the larval stage of Chrysoperla externa. (A) first instar of Chrysoperla externa; (B) second instar of Chrysoperla externa; (C) third instar of Chrysoperla externa. (Images recorded with 13 Mpx camera. Surfboard (A, B and C), with the aid of a stereoscopic microscope with a magnification of 20x). Figure S2: Mortality Confirmed. (A) Larva of Chrysoperla externa dead after $120 \mathrm{~h}$, treatment with B. bassiana; (B) larvae after the surface disinfection process; $(C)$ Larvae over humid chamber containing sterile cotton moistened with distilled water to provide mycelial growth; (D) Storage of humid chambers in B.O.D. at $25 \pm 1{ }^{\circ} \mathrm{C},(\mathrm{RH})$ $70 \pm 10 \%$ and $12 \mathrm{~h}$ photoperiod (L: D). (Images recorded with $13 \mathrm{Mpx}$ camera. With the aid of a stereoscopic microscope with a magnification of 20x). Figure S3: Visual scale for viability or deformity of Chrysoperla externa. (A and B) Insects with wing and antenna deformity patterns; (C) Viable insect. (Images recorded with $13 \mathrm{Mpx}$ camera. With the aid of a stereoscopic microscope with a magnification of 20X). Figure S4: Conidiogenesis of Beauveria bassiana (ESALQ PL63 strain), on cadavers of Chrysoperla externa with mortality at 120 hours after application. (A) confirmed mortality by the fungus Beauveria bassiana $\left(1 \times 10^{7} \mathrm{con} \cdot \mathrm{mL}^{-1}\right)$, (D.A.), on dead bodies of second instar of Chrysoperla externa, 5 days after mortality; (B) Conidiogenesis on third instar larvae, 3 days after the death $\left(1 \times 10^{8} \mathrm{con} \cdot \mathrm{mL}^{-1}\right)$, (D.O.); (C) conidiogenesis of Beauveria bassiana $\left(1 \times 10^{9} \mathrm{con} \cdot \mathrm{mL}^{-1}\right)$, (D.A.), on dead bodies of third instar, 3 days 39 after death. (Images recorded with $13 \mathrm{Mpx}$ camera. With the aid of a stereoscopic microscope with a 40 magnification of 20x). Figure S5: Emergence of Chrysoperla externa after application of treatments on third instar larvae. (A) The emergence of C. externa, treatment with B. bassiana $\left(1 \times 10^{9}\right.$ conidia

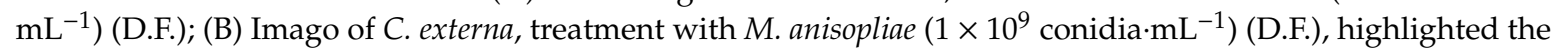
antennas and the golden eyes, characteristic of the group green lacewing; $(C)$ adults of C. externa, regular size, control treatment (D.A.). (Images recorded with $13 \mathrm{Mpx}$ camera. With the aid of a stereoscopic microscope with a magnification of 20x). Table S1: Summary of ANOVA (values of mean square) of the mortality of first instar (larval) period of C. externa after application of entomopathogenic fungi B. bassiana, M. anisopliae and M. rileyi (T: $25 \pm 1{ }^{\circ} \mathrm{C}$, RH of $70 \pm 10 \%$ and photoperiod of $12 \mathrm{~h}$ (L:D)). Table S2: Summary of ANOVA (values of mean square) of the mortality of second instar (larval) period of C. externa after application of entomopathogenic fungi B. bassiana, M. anisopliae and M. rileyi (T: $25 \pm 1{ }^{\circ} \mathrm{C}, \mathrm{RH}$ of $70 \pm 10 \%$ and photoperiod of $12 \mathrm{~h}$ (L:D)). Table S3: Summary of ANOVA (values of mean square) of the mortality of third instar (larval) period of $C$. externa after application of entomopathogenic fungi B. bassiana, M. anisopliae and M. rileyi (T: $25 \pm 1{ }^{\circ} \mathrm{C}, \mathrm{RH}$ of $70 \pm 10 \%$ and photoperiod of $12 \mathrm{~h}(\mathrm{~L}: \mathrm{D}))$. Table S4: Summary of ANOVA (values of mean square) of the duration of first instar (larval) period of C. externa after application of the entomopathogenic fungi B. bassiana, M. anisopliae and M. rileyi (T: $25 \pm 1{ }^{\circ} \mathrm{C}$, RH of $70 \pm 10 \%$ and photoperiod of $12 \mathrm{~h}(\mathrm{~L}: \mathrm{D})$ ). Table S5: Summary of ANOVA (values of mean square) of the duration of second instar (larval) period of C. externa after application of the entomopathogenic fungi B. bassiana, M. anisopliae, and M. rileyi (T: $25 \pm 1{ }^{\circ} \mathrm{C}, \mathrm{RH}$ of $70 \pm 10 \%$ and photoperiod of $12 \mathrm{~h}$ (L:D)). Table S6: Summary of ANOVA (values of mean square) of the duration of third instar (larval) period of C. externa after 
application of the entomopathogenic fungi B. bassiana, M. anisopliae, M. rileyi (T: $25 \pm 1{ }^{\circ} \mathrm{C}, \mathrm{RH}$ of $70 \pm 10 \%$ and photoperiod of $12 \mathrm{~h}$ (L:D)). Table S7: Summary of ANOVA (values of mean square) of the duration of third instar (larval) period and pupae of C. externa after application of the entomopathogenic fungi B. bassiana, M. anisopliae, M. rileyi (T: $25 \pm 1{ }^{\circ} \mathrm{C}, \mathrm{RH}$ of $70 \pm 10 \%$ and photoperiod of $12 \mathrm{~h}(\mathrm{~L}: \mathrm{D})$ ).

Author Contributions: Conceptualization, P.M.D., E.d.S.L. and L.G.A.P.; methodology, P.M.D., E.d.S.L. and L.G.A.P.; funding acquisition, E.d.S.L.; supervision, P.M.D. and E.d.S.L.; project administration, P.M.D.; Data curation, P.M.D., G.L.R.D., G.B.B.J. and A.M.W.; validation, P.E.T.; formal analysis, P.E.T.; writing-original draft preparation, P.M.D., E.d.S.L., L.G.A.P. and A.A.N.; writing-review and editing, P.M.D., E.d.S.L., L.G.A.P. and A.A.N.; All authors have read and agreed to the published version of the manuscript.

Funding: This research was funded by (FUNDECT)—Foundation to Support the Development of Education, Science and Technology of the State of Mato Grosso do Sul, MS, Brazil, grant number (59/300.513/2016).

Acknowledgments: We thank the Graduate Program of Entomology and Biodiversity Conservation, PPGECB-UFGD, Dourados, MS The Fundação de Apoio ao Desenvolvimento de Ensino Ciência e Tecnologia do Estado de Mato Grosso do Sul (FUNDECT). This study was financed in part by the Coordenação de Aperfeiçoamento de Pessoal de Nível Superior-Brasil (CAPES), finance Code 001; The Conselho Nacional de Desenvolvimento Científico e Tecnológico (CNPq), finance code: 001 (CNPq), finance code: 001; The Federal University of Mato Grosso do Sul, (UFMS), for the resources to publish this manuscript; The members of the research group LAMIP.

Conflicts of Interest: The authors declare no conflict of interest.

\section{References}

1. Oswald, J.D. Neuropterida Species of the World. 2018. Available online: http://lacewing.tamu.edu/ SpeciesCatalog/Main \T1\textgreater \{\} (accessed on 3 January 2020).

2. Maia, W.J.M.S.C.; Souza, B.; Cruz, I.; Maia, T.J.A.F. Rhopalosiphum maidis (Fitch, 1856) (Hemiptera: Aphididae). Ciênc. Agrotecnol. 2004, 28, 1259-1268. [CrossRef]

3. Pessoa, L.G.A.; Leite, M.V.; de Freitas, S.; Garbin, G.C. Efeito da variação da temperatura sobre o desenvolvimento embrionário e pós embrionário de Ceraeochrysa paraguaria (Navás) (Neuroptera: Chrysopidae). Arq. Inst. Biol. 2004, 71, 473-476.

4. Pitwak, J.; Menezes, A.O., Jr.; Ventura, M.U. Development and reproductive performance of Chrysoperla externa (Neuroptera: Chrysopidae) using preys from wheat crop. Rev. Colomb. Entomol. 2016, 42, 118-123. [CrossRef]

5. Pasini, R.A. Seletividade de Agrotóxicos Utilizados na Cultura do Trigo aos Predadores Chrysoperla Externa (Hagen, 1861) (Neuroptera: Chrysopidae) e Eriopis Connexa (Germar, 1824) (Coleoptera: Coccinellidae) em Condições de Laboratório e Semi-Campo. Tese (Doutorado) Programa de Pós-Graduação em Fitossanidade; Universidade Federal de Pelotas: Pelotas, Brazil, 2017; p. 154. (In Portuguese)

6. De Silva, B.K.A.; de Godoy, M.S.; de Lima, A.G.; de Oliveira, A.K.S.; Pastori, P.L. Toxicity of insecticides used in muskmelon on first-instar larvae of Chrysoperla genanigra Freitas (Neuroptera: Chrysopidae). Rev. Caatinga 2017, 30, 662-669. [CrossRef]

7. Hewlett, J.A.; Eubanks, M.D. The effects of sugarcane aphid density in sorghum on predation by lady beetles and lacewings. Biol. Control. 2018, 129, 171-177. [CrossRef]

8. De Armas, F.S.; Grützmacher, A.D.; Nava, D.E.; Rakes, M.; Bueno, F.A.; Pasini, R.A. Selectivity of pesticides used in peach orchards to eggs and pupae of the predators Chrysoperla externa and Coleomegilla quadrifasciata. Semin. Ciênc. Agrár. 2019, 40, 1427-1440. [CrossRef]

9. Santos, T.M.; Junior, A.L.B.B.; Soares, J.J. Influência de tricomas do algodoeiro sobre os aspectos biológicos e capacidade predatória de Chrysoperla externa (Hagen) alimentada com Aphis gossypii Glover. Bragantia 2003, 14, 243-254. [CrossRef]

10. Bezerra, C.E.S.; Nogueira, C.A.F.; Shadow, M.C.D.S.; Demartelaere, A.C.C.; Araujo, E.L. Green lacewings (Neuroptera: Chrysopidae): Biological Aspects, potential use and future perspectives. Rev. Caatinga 2009, 22, $1-5$.

11. Alberquerque, S.A. Green lacewings (Neuroptera: Chrysopidae). In The Bioecology and Nutrition of Insects: Basis for the Integrated Management of Pests, 1st ed.; Panizzi, A.R., Parra, J.R.P., Eds.; Embrapa Technological Information: Brasilia, Brazil, 2009; Volume 23, pp. 969-1022.

12. Bortoli, S.A.; Caetano, A.C.; Murata, A.T.; Oliveira, J.E.M. Development and predatory viability of Chrysoperla externa (Hagen) (Neuroptera: Chrysopidae) in different prey. Bioterra 2006, 6, 152-154. 
13. Murata, T.; Caetano, C.; Bortoli, S.A.; Brito, C.H. Capacity of consumption of Chrysoperla externa (Hagen, 1861) (Neuroptera: Chrysopidae) in different prey. Rev. Caatinga 2006, 19, 304-309.

14. Albuquerque, D.F.A.; Cruz, I. Biological Aspects of Chrysoperla externa (Hagen, 1861) (Neuroptera: Chrysopidae) having as a source of food eggs of Helicoverpa armigera (Hübner) (Lepidoptera: Noctuidae). Seminar on Scientific Initiation Program PIBIC/BIC JÚNIOR, 2017, Sete Lagoas (submitted paper). In Proceedings of the Sete Lagoas: Embrapa Maize and Sorghum, Sete Lagoas, Brazil, 17 August 2017; Available online: https://www.alice.cnptia.embrapa.br/alice/handle/doc/1074573/ (accessed on 10 August 2019).

15. Lacey, L.A.; Grzywacz, D.; Shapiro-Ilan, D.I.; Frutos, R.; Brownbridge, M.; Goettel, M.S. Insect pathogens as biological control agents: Back to the future. J. Invert. Pathol. 2015, 132, 1-41. [CrossRef] [PubMed]

16. Zimmermann, G. The entomopathogenic fungi Isaria farinose (formerly Paecilomyces farinosus) and the Isaria fumosorosea species complex (formerly Paecilomyces fumosoroseus): Biology, ecology and use in biological control. Biocont. Sci. Technol. 2008, 18, 865-901. [CrossRef]

17. Mora, M.A.E.; Castilho, A.M.C.; Fraga, M.E. Fungos entomopatogenicos: Enzimas, toxinas e fatores que afetam a diversidade. Rev. Bras. Prod. Agroind. 2016, 18, 335-349. [CrossRef]

18. Fathipour, Y.; Sedaratian, A. integrated management systems of cultivation of soy Helicoverpa armigera. In Elshemy Ha Resistance a Pests of Soybeans; InTeOpP: Cairo, Egypt, 2013; pp. 231-280.

19. De Bueno, A.F.; Carvalho, G.A.; dos Santos, A.C.; Sosa-Gómez, D.R.; da Silva, D.M. Pesticide selectivity to natural enemies: Challenges and constraints for research and field recommendation. Ciênc. Rural 2017, 47, 1-10. [CrossRef]

20. Fernandes, F.L.; Bacci, L.; Fernandes, M.S. Impact and selectivity of insecticides to predators and parasitoids. EntomoBrasilis 2010, 3, 1-10. [CrossRef]

21. De Bueno, A.F.; Batistela, M.J.; de Bueno, R.C.O.F.; de França-Neto, J.B.; Nishikawa, M.A.N.; Filho, A.L. Effects of integrated pest management, biological control and prophylactic use of insecticides on the management and sustainability of soybean. Crop. Prot. 2011, 30, 937-945. [CrossRef]

22. Ndakidemi, B.; Mtei, K.; Ndakidemi, P.A. Impacts of synthetic and botanical pesticides on beneficial insects. Agric. Sci. 2016, 07, 364-372. [CrossRef]

23. Sosa-Gómez, D.R. Seletividade de agroquímicos para fungos entomopatogênicos. Embrapa Soja Outras Publicações Científicas. 2005. Available online: https://ainfo.cnptia.embrapa.br/digital/bitstream/CNPSO-200909/28931/1/seletiv_fung.pdf (accessed on 24 August 2020).

24. Rimoldi, F.; Schneider, M.I.; Ronco, A. Short and long-term effects of endosulfan, cypermethrin, spinosad, and methoxyfenozide on adults of Chrysoperla externa (Neuroptera: Chrysopidae). J. Econ. Entomol. 2012, 105, 1982-1987. [CrossRef] [PubMed]

25. Rugno, G.R.; Zanardi, O.Z.; Yamamoto, P.T. Are the Pupae and Eggs of the Lacewing Ceraeochrysa cubana (Neuroptera: Chrysopidae) Tolerant to Insecticides? J. Econ. Entomol. 2015, 108, 2630-2639. [CrossRef]

26. Pasini, R.A.; Grützmacher, A.D.; de Pazini, J.B.; de Armas, F.S.; Bueno, F.A.; Pires, S.N. Side effects of insecticides used in wheat crop on eggs and pupae of Chrysoperla externa and Eriopis connexa. Phytoparasitica 2018, 46, 115-125. [CrossRef]

27. De Soares, A.F.; Carvalho, G.A. Physiological selectivity of insecticides to eggs and larvae of predator Chrysoperla externa (HAGEN) (Neuroptera: Chrysopidae). Coffee Sci. 2018, 13, 292-303. [CrossRef]

28. Rugno, G.R.; Zanardi, O.Z.; Parra, J.R.P.; Yamamoto, P.T. Lethal and Sublethal Toxicity of Insecticides to the Lacewing Ceraeochrysa cubana. Neotrop. Entomol. 2019, 48, 162-170. [CrossRef] [PubMed]

29. Generoso, A.R. Compatibility of Beauveria bassiana and Paecilomyces fumosoroseus with Chrysoperla externa (Neuroptera: Chrysopidae) and Methodology for Evaluating Selectivity. Master's Thesis, Paulista State University, Jaboticabal-SP, Brazil, 2002; p. 63.

30. Pessoa, L.G.A.; Cavalcanti, R.S.; Junior, A.M.; Souza, B. Compatibility between Beauveria bassiana and predator Chrysoperla externa in the laboratory. Pesq. Agropecu. Bras. 2005, 40, 617-619. [CrossRef]

31. Cardoso, E.R.; Freitas, S.; Nunes, H.T.; Pessoa, L.G.A. Selectivity of Lecanicillium lecanii and Metarhizium anisopliae for first instar larvae of Ceraeochrysa cincta (Neuroptera: Chrysopidae) in laboratory. Acta Sci. Agron. 2007, 29, 563-568. [CrossRef]

32. Schlick, E.C.; Toscano, L.C.; Souza, G.D.; Peres, A.J.A.; Dias, P.M.; Maruyama, W.I. Compatibilidade de Metarhizium anisopliae (Metschnikoff) Sorokin (Hypocreales: Clavicipitaceae) com Chrysoperla externa (Hagen) (Neuroptera: Chrysopidae). EntomoBrasilis 2015, 8, 189-195. 
33. Consechi, M.R. Parâmetros a Serem Considerados nas Pulverizações do Fungo Isaria Fumosorosea Para o Manejo de Diaphorina Citri. Doctor's Thesis, University of São Paulo—School of Agriculture “Luiz de Queiroz", Piracicaba-SP, Brazil, 2017; p. 134. (In Porutguese).

34. Dias, P.M.; Filho, L.M.A.; Pessoa, L.G.A.; Loureiro, E.S.; Ramalho, K.F. Production of Metarhizium rileyi in different mixtures of rice and sorghum. In Proceedings of the XII Agronomic Week Cassilândia \& V Week of Research of the Post-Graduation, Cassilândia-MS, Brazil, 12 September 2017; p. 99.

35. Ribeiro, M.J. Biology of Chrysoperla externa (Hagen, 1861) (Neuroptera, Chrysopidae) Fed with Different Diets. Master's Thesis, School of Agriculture of Lavras, Lavras-MG, Brazil, 1988; p. 131.

36. Dias, P.M.; Loureiro, E.S.L.; Pessoa, L.G.A.; Neto, F.M.O.; Tosta, R.A.S.; Teodoro, P.E. Interactions between Fungal-Infected Helicoverpa armigera and the Predator Chrysoperla externa. Insects 2019, 10, 309. [CrossRef]

37. Thungrabeab, M.; Angma, S. Effect of entomopathogenic fungus, Beauveria bassiana (BALSAM) and Metarhizium anisopliae (Metsch) on non-target insects. KMITL Sci. Technol. J. 2007, 7, 1-10.

38. Hassan, S.A. Standardized techniques for testing side-effects of pesticides on beneficial arthropods in the laboraary. ZeitscbriflfUr Pflanz. FIanzenscbutz 1977, 84, 158-163.

39. Hassan, S.A. Standard methods a test the Sideeffects of pesticides on natural enemies of insects and mites developed by the IOBC/WPRS Wprk Group ‘Pesticides and Benefitial Organisms'. EPPO Bull. 1985, 15, 214-255. [CrossRef]

40. Freitas, S.; Penny, N.D. The green lacewings (Neuroptera: Chrysopidae) of Brazilian agro-ecosystems. Acad. Sci. 2001, 50, 245-395.

41. Bhering, L.L. Rbio: A Tool for Biometric And Statistical Analysis Using The R Platform. Crop. Breed. Appl. Biotech. 2017, 17, 187-190. [CrossRef]

42. Alves, S.B.; Lopes, R.B. Microbial Control of Pests in Latin America; FEALQ: Piracicaba, Brazil, 2008; p. 414.

43. Alves, S.B.; Milk, L.H.; Filho, A.B.; Almeida, J.E.M.; Marques, E.J. Massal production of entomopathogenic fungi in Latin America. In Microbial Control of Pests in Latin America, 2nd ed.; Alves, S.B., Lopes, R.B., Eds.; FEALQ: Piracicaba, Brazil, 2008; pp. 215-237.

44. Leger, R.J.; Wang, C. Genetic engineering of fungal biocontrol agents to achieve efficacy against insect pests. Appl. Microb. Biotechnol. 2010, 85, 901-907. [CrossRef] [PubMed]

45. Wang, C.; Feng, M.G. Advances in fundamental and applied studies in china of fungal biocontrol agents for use against arthropod pests. Biol. Control. 2014, 68, 129-135. [CrossRef]

46. Alves, S.B.; Moino, J.R.A.; Almeida, J.E.M. Produtos fitossanitários e entomopatógenos. In Controle Microbiano de Insetos; Alves, S.B., Ed.; Fealq: Piracicaba, Brazil, 1998; pp. 217-238.

47. Ausique, J.J.S.; D’Alessandro, C.P.; Conceschi, R.M.; Mascarin, G.M.; Delalibera, I.J. Efficacy of entomopathogenic fungi against adults of Diaphorina citri for field laboratory applications. J. Pest. Sci. 2017, 90, 947-960. [CrossRef]

48. Arnosti, A.; Junior, I.D.; Conceschi, M.R.; D'Alessandro, C.P.; Travaglini, R.V.; Camargo-Mathias, M.I. Interactions of adjuvants on adhesion and germination of Isaria fumosorosea on adults of Diaphorina citri. Sci. Agric. 2019, 76, 487-493. [CrossRef]

49. Alves, S.B.; Padua, L.E.M.; Azevedo, E.M.V.M.; Almeida, L.C. Controle da broca da cana-de-acucar pelo uso de Beauveria bassiana. Pesq. Agrop. Bras. 1985, 20, 403-406.

50. Faria, L.L.F.; Oliveira, J.V.; Barros, R. Patogenicidade do fungo Beauveria bassiana (Bals.) Vuill., em lagartas de Spodoptera frugiperda (J. E. Smith, 1797) (Lepidoptera, Noctuidae) sob condições de Laboratorio. Cad. Omega Sér. Agron. 1992, 4, 207-217.

51. Lecuona, R.E.; Tigano, M.S.; Diaz, B.M. Characterization and pathogenicity of Beauveria bassiana against Diatraea saccharalis (F.) (Lepidoptera; Pyralidae) in Argentina. An. Soc. Entomol. Bras. 1996, 25, $299-307$.

52. Silva, R.B.Q.; Veiga, A.F.S.L. Patogenicidade de Beauveria bassiana (Bals.) e Metarhizium anisopliae (Metsch.) Sorok. sobre Castnia icarus (Cramer, 1775). Rev. Agric. 1998, 73, 119-127.

53. Leyva, O.E.; Villalon, E.M.; Ávila, R.A.; Bulet, D.B.B. Susceptibilidad de Chrysopa exterior Navas a Beauveria bassiana (Blasamo) Vuillemin cepa LBB-1 en condiciones de laboratorio. Fitosanidad 2011, 15, 51-57.

54. López, M.A.C.; Osorio, J.W.M. Compatibilidad de Beauveria bassiana Y Metarhizium anisopliae com Chrysoperla externa depredador de Trialeurodes vaporariorum. Chliean J. Agric. Anim. Sci. 2019, 35, 38-48. 
55. Ventura, M.A.; Ribeiro, C.; Garcia, V. Susceptibility of third instar larvae of the green lacewing Chrysoperla kolthoffi (Navas) (Insecta: Neuroptera: Chrysopidae) to the entomopathogenic fungus Metarhizium anisopliae (Metschnikoff) Sorokin var. anisopliae Tulloch in the laboratory. In Proceedings of the Fifth International Symposium on Neuropterology, Cairo, Egypt, 2-6 May 1994; pp. 241-249.

56. Ventura, M.A.; Garcia, V.; Canard, M. Efeito da antibiose causado pelo fungo entomopatogênico Metarhizium anisopliae (Metschnikoff) Sorokin variedade anisopliae Tulloch, a uma "crisopideo verde comum" Chrysoperla kolthoffi (Navás) (Neuroptera: Chrysopidae). J. Neuropterol. 2000, 3, 33-41.

57. Maia, W.J.S.; Carvalho, C.F.; Souza, B. Exigências térmicas de Chrysoperla externa (Hagen, 1861) (Neuroptera: Chrysopidae) alimentada com Schizaphis graminum (Rondani, 1852) (Hemiptera: Aphididae) em condições laboratório. Ciênc. Agrotecnol. 2000, 24, 81-86.

58. Silva, C.G. Desenvolvimento das fases imaturas de Chrysoperla externa alimentadas com ninfas de Bemisia tabaci criadas em três hospedeiros. Pesq. Agrop. Bras. 2004, 39, 1065-1070. [CrossRef]

59. Gupta, S.; Krasnoff, S.B.; Roberts, D.W.; Renwick, J.A.A.; Brinen, L.S.; Clardy, J. Structure of efrapeptins from the fungus Tolypocladium niveum: Peptide inhibitors of mitochondrial ATPase. J. Org. Chem. 1992, 57, 2306-2313. [CrossRef]

60. Vestergaard, S.; Gillespie, A.T.; Butt, T.M.; Schreiter, G.; Eilenberg, J. Pathogenicity of the Hyphomycete fungi Verticillium lecanii and Metarhizium anisopliae to the western thrips, Frankliniella occidentalis. Biocont. Sci. Technol. 1995, 5, 185-192. [CrossRef]

61. Leal, S.C.M.; Bertioli, D.J.; Butt, T.M.; Carter, J.H.; Burrows, P.R.; Peberdy, J.F. Amplification and restriction endonuclease digestion of the Pr1 gene for the detection and characterization of Metarhizium anisopliae. Mycol. Res. 1997, 101, 257-265. [CrossRef]

62. Lacey, L.A.; Goettel, L.A. Current developments in microbial control of insect pests and prospects for the early 21st century. Entomophaga 1995, 40, 3-27. [CrossRef]

63. Hajek, A.E.; Eastburn, C.C. Attachment and germination of Entomophaga maimaiga conidia on host and non-host larval cuticle. J. Invertebr. Pathol. 2003, 82, 12-22. [CrossRef]

64. Bianco, L.; Perrota, G. Methodologies and perspectives of proteomics applied to filamentous fungi: From sample preparation to secretoma analisys. Int. J. Mol. Sci. 2015, 16, 5803-5820. [CrossRef] [PubMed]

65. Ruiz, A.C. Virulência de Nomuraea rileyi à Spodoptera frugiperda e Perfil Protéico do Secretoma em Presença da Cutícula do Inseto. Master's Thesis, University of Caxias do Sul, Rio Grande do Sul-RS, Brazil, 2016; p. 38. (In Portuguese)

66. Portilla, M.; Snodgrass, G.; Luttrell, R. Lethal and Sub-Lethal Effects of Beauveria bassiana (Cordycipitaceae) Strain NI8 on Chrysoperla rufilabris (Neuroptera: Chrysopidae). Flor. Entomol. 2017, 100, 627-633. [CrossRef]

67. Portilla, M.; Luttrell, R.; Snodgrass, G.; Zhu, Y.C.; Riddick, E. Lethality of the entomopatoghenic fungus Beauveria bassiana NI8 strain in Lygus lineolaris (Hemiptera: Miridae) and its possible impact on beneficial arthropods. J. Entomol. Sci. 2017, 52, 352-369. [CrossRef]

Publisher's Note: MDPI stays neutral with regard to jurisdictional claims in published maps and institutional affiliations.

(C) 2020 by the authors. Licensee MDPI, Basel, Switzerland. This article is an open access article distributed under the terms and conditions of the Creative Commons Attribution (CC BY) license (http://creativecommons.org/licenses/by/4.0/). 